\title{
THE IMPORTANCE OF CONTENT KNOWLEDGE FOR SUCCESSFUl LEGAL LANGUAGE ACQUISITION
}

\author{
SNJEŽANA HUSINEC \\ shusinec@pravo.hr \\ Faculty of Law, University of Zagreb, Croatia
}

\begin{abstract}
One of the most difficult tasks in the instruction of legal language is teaching highly specific legal terminology. Although some legal terms are widely used in ordinary language, there are some words and phrases which seem familiar, but have an unexpected meaning for a layperson. Additionally, there is a number of terms with specific legal meanings which presuppose some knowledge of legal content to be fully understood. On the other hand, since legal language is shaped by the legal system in which it is used, legal terms reflect particular legal systems and differences between them and are therefore inseparable from the law.

This paper examines what implications this interconnection between language and law has on the process of legal language instruction and acquisition. How important is the knowledge of legal content for successful acquisition of legal terminology? What is the best approach to teaching such content-dependant language and what amount of background information needs to be taught? To answer these questions, the author analyses the results of a survey conducted among the law students attending legal language courses at the Faculty of Law in Zagreb and combines it with theoretical research and her teaching experience.
\end{abstract}

Key words: instruction and acquisition of legal terminology, legal language courses, importance of legal content

\section{Introduction}

The very nature of legal language makes it a very difficult language to teach. In order to develop the learners' linguistic ability and ensure their successful communication in the field of law a legal language teacher needs to deal with specialized text structures, extreme formality of legal documents, long and complex sentence structures and highly specialized vocabulary. In this process of teaching legal language special attention must be given to the teaching of highly specific legal terminology with very specific legal meaning, which usually presupposes some legal knowledge to be understood. Namely, "the law and its practitioners have developed a range of unique legal concepts, and these can be expressed efficiently only by using legal jargon" (Gibbons 286: 2006). Since legal concepts are shaped by the legal system in which they have been developed and are used, legal terms as their verbal expressions, besides reflecting their content, also reflect particular legal cultures and dissimilarities between them. Therefore, they are 
inseparable from the law. Such close interconnection between legal language and the law unavoidably has strong implications on the process of legal language acquisition and requires a special methodological approach to its instruction.

This paper examines the implications of the interconnection between language and law on the legal language instruction and acquisition and discusses the role of the knowledge of legal content in the legal language study. On basis of the results of a survey conducted among the law students attending legal English courses at the Faculty of Law in Zagreb, some theoretical research and the author's teaching experience we will try to prove the importance of content knowledge for successful legal language acquisition and the need for an integrated language and content approach to teaching legal language.

\section{Integrating language and content in LLP instruction}

One of the core characteristics of languages for specific purposes is close relation between language instruction and the subject matter. Contents of various disciplines provide frameworks for LSP courses. Since interdisciplinarity is undoubtedly a key feature of LSP courses, it does not surprise that the integration of language and content has become one of the major issues in the discussion on the course design of various LSP courses.

Since legal language is, owing to its specificity, inseparable from the law and the legal system in which it is used, the need for interdisciplinarity in legal language courses is even greater than in other LSP courses. In order to understand exact meanings of legal terms the learners of legal languages need to know about the law. They need to understand legal concepts as they have developed and are used in a foreign legal system and need to be able to compare it with their national legal system. Therefore, their study of legal language can be sufficiently successful only if they have some expertise of the law from their earlier study or work experience and if they study language through content and context. The central questions arising from the above facts are: how should language and content be integrated in a legal language course, and which methodology is the most appropriate for teaching such content-dependent language?

Content-based instruction (CBI) may be the answer to both questions. It is a relatively new methodological approach in second language acquisition which refers to "the concurrent study of language and subject matter" (Brinton et al., 1989: vii) and represents a shift from the traditional bottom-up approaches in foreign language teaching. So far various models of CBI have been implemented in a number of educational settings and it has become quite popular on the language teaching scene (Juez, 2006: 327). CBI integrates particular content with language teaching aims and teaches concurrently language skills and subject matter where syntax, morphology and semantics of the particular legal area are studied within the specific context.

"During content-based instruction attention is shifted from learning language per se to learning language through a relevant learning context. Communicative competence is achieved in the process of learning about specific topics" (Juez, 2006: 328). 
Such a model of teaching supports learning language through specialist content and in its original context and therefore seems to be the most appropriate for legal language instruction.

\section{Content-based legal language instruction at the Faculty of law in Zagreb}

Having taken into consideration all the specificities of legal language instruction and acquisition and the specific circumstances in which legal languages are taught at the Faculty of law in Zagreb as well as the benefits of CBI, content-based instruction has been adopted as the most appropriate approach for the two-year courses of legal English at our Law faculty. The courses are compulsory and have been developed for the first and second year students with the main goal to introduce them to basic legal concepts and terminology and to improve their ability to read and understand legal texts in a foreign language, as well as to familiarize them with the general aspects of foreign legal systems. The courses are primarily language courses and are taught by language and not by content teachers. Although transmission of content knowledge is only secondary here, in order to teach legal language effectively a content-based instruction as the most effective methodological approach has been applied.

The course "Legal English" is a theme-based course, which within sixty 90-minuteclasses throughout four semesters covers 36 topics related to different areas and aspects of English and American law. Through different activities focusing on the content related to the English and American legal systems, i.e. within the specific context, the law students study specific legal concepts and terms, syntax and morphology and develop their linguistic ability in the particular areas of law.

All classes follow a similar pattern. The first part of each class focuses on the main features of the English or American judicial system (eg. court systems, institutions, legal principles ...) in a particular area or sub-area. An overview is usually given by a teacher in an interactive presentation within which foreign legal terminology is defined and possible equivalents in the Croatian legal system are discussed. Such presentations are meant to demonstrate and develop meaningful use of language in context and teach legal terminology through context and content. By learning about legal principles, traditions, institutions, legal procedures etc. the students are confronted with the important factual and linguistic features of Anglo-Saxon law and they develop their awareness of similarities and differences between the Croatian and English/American judicial system, concepts and terminology. After the intensive content-based study, students focus on a text in the textbook on the same topic or an aspect of the same topic. In this second section the approach to language learning is more traditional - reading comprehension is practiced, terminology analyzed and practiced and structural and stylistic aspects of the language are discussed, but with the constant awareness of the broader contentframework given in the first section.

The presented methodological approach has proven the most rewarding one in our specific teaching circumstances. Namely, the course, which presupposes certain knowledge of law is attended at the very beginning of the law degree programme (the first and second year) when the students have no legal knowledge of their national law 
yet, let alone another judicial system, and have absolutely no awareness of considerable differences between legal systems. In addition, legal English at our Law faculty is taught to huge groups of over 100 students, which makes the teacher-student interaction extremely difficult and requires an even more careful planning and course design.

\section{The survey}

\subsection{Research objective, target group and method}

In order to fully evaluate the efficiency of a course and the applied approach and further improve it, it is necessary to learn about the students' perception of its efficiency. For this purpose a survey was conducted among the first and second year law students who attend legal English courses at the Faculty of Law, University of Zagreb. The objective of the survey was to discover how efficient the students find the integrated content and language approach to legal English learning and how important they find the content knowledge for the successful mastering of legal language and legal terminology in particular. The survey was descriptive and the participants were requested to respond to a brief questionnaire. The students' responses were then statistically analyzed. There were all together 214 respondents, half of them in the first year of their study, who had been studying legal English for a semester, and one half who had a history of studying legal English in a university setting for a year and a half.

\subsection{Questionnaire description}

The questionnaire consisted of three parts. The questions were mainly multiple-choice and scaled questions with two open-ended questions included. The responses to questions in the first section intended to reveal how homogeneous the group is concerning the length of their study of general English and their self-assessed level of general English. In this section the respondents were also asked to assess their knowledge of law, of Croatian legal terminology and legal English before starting the legal English course at the university. Section II focused on their actual attitudes towards the importance of content knowledge and the appropriate teaching approach for successful acquisition of legal English language and terminology in particular. In scaled questions the respondents rated the importance of general English, legal terminology and legal systems as well as different sources of knowledge for successful acquisition of legal terminology. In a multiple choice question the respondents were expected to select the most effective method(s) for the legal terminology acquisition and in an open-ended question, which followed, they pointed out the problems they encountered during their legal terminology study. Section III focused on the students' opinions concerning the best time to start a legal English course within a law degree programme and their selfassessed success in legal English study. 


\subsection{The survey results and data analysis}

\subsubsection{Section I}

The data collected in first section of the questionnaire revealed that the group is very homogeneous concerning both the length of their study and their self-assessed level of general English. So, the majority of respondents have been studying English for either 9 $(34,6 \%)$ or 12 years $(29 \%)$ or even longer $(26,2 \%)$ and assessed their knowledge of general English either as very good $(47,2 \%)$ or good $(29,4 \%) .20,1 \%$ even thought their command of general English was excellent. So, obviously, their level of general English cannot be an obstacle in learning legal English. Concerning their knowledge of legal content before the beginning of their legal studies the vast majority of students claimed that they were familiar with only some general legal terms which belong to everyday language (75\%) and that they never had any contact with legal English $(77,5$ $\%)$. A lower percentage (18,7 \%) knew some English legal terms, which they learned mostly by watching movies and other TV programmes on legal topics on Croatian TV. So, in both, legal English and legal content study most students were beginners.

\subsubsection{Section II}

In the second part of the questionnaire the students rated on a scale from 1 to 5 ( 1 for unimportant and for 5 extremely important) the importance of general English, the knowledge of national legal terminology, the legal knowledge of a particular area of the national legal system and English legal system for their understanding and successful learning of English legal terminology. The data collected in this section show that almost $40 \%$ of all respondents think that it is very important to be familiar with the legal vocabulary of your national system (of a specific area of law that you study in English) to be successful in acquiring English legal terminology. 23,4 \% more thought it was extremely important, whereas $29 \%$ rated it as important. So, overall, over $90 \%$ of all respondents are aware of the importance of having firs the knowledge of national legal system and terminology in their mother tongue in order to master the foreign legal terminology successfully. They find somewhat less important the knowledge of the particular branch of Croatia law for the study of the language of the same area of English law. Nevertheless, over $80 \%$ highly value this knowledge and think it is of importance for the acquisition of English legal terminology. 34,6 \% find it very important and 8,9\% extremely important, whereas $39,3 \%$ thought it was just important. A similar percentage of respondents rated the knowledge of the English legal system in the studied area as important $(40,2 \%)$ whereas $25,7 \%$ thought it is very important or even extremely important $(11,7 \%)$. All in all $77,3 \%$ of all students find such knowledge important for their successful study of legal English.

Therefore, we can conclude that content knowledge of both the national legal system and English legal system in the area that is being studied as well as the knowledge of Croatian legal terminology prior to the study of English legal terminology is of importance for the majority of students. However, it can be noted, that they attach a 
slightly higher value to the knowledge of terminology in their national system that the actual content of the particular branch of law in both legal systems.

Table 1-1. Students' perception of the importance of legal knowledge for successful acquisition of English legal terminology

\begin{tabular}{|c|c|c|c|c|c|}
\hline & Unimportant & $\begin{array}{c}\text { Less } \\
\text { important }\end{array}$ & Important & $\begin{array}{c}\text { Very } \\
\text { important }\end{array}$ & $\begin{array}{c}\text { Extremely } \\
\text { important }\end{array}$ \\
\hline $\begin{array}{c}\text { Legal terms in Croatian } \\
\text { law }\end{array}$ & $0,9 \%$ & $7,5 \%$ & $29,0 \%$ & $39,3 \%$ & $23,4 \%$ \\
\hline $\begin{array}{c}\text { Knowledge of area of } \\
\text { Croatian law }\end{array}$ & $1,9 \%$ & $15,4 \%$ & $39,3 \%$ & $34,6 \%$ & $8,9 \%$ \\
\hline $\begin{array}{c}\text { Knowledge of area of } \\
\text { English law }\end{array}$ & $3,7 \%$ & $18,7 \%$ & $40,2 \%$ & $25,7 \%$ & $11,7 \%$ \\
\hline
\end{tabular}

In the next scaled question the respondents were asked to identify the level of importance of particular sources of knowledge for their successful study of English legal terminology. The responses to this question revealed that the text book is very important to them (38,3\% very important, 31,8 \% important, 17,8 \% extremely important), whereas they find bilingual and monolingual dictionaries somewhat less important (bilingual slightly more important than monolingual - see Table 2). Legal encyclopedias and additional reading in English on legal topics was by a third of all respondents indicated as less important, whereas another third thought it was important (but not very or extremely important). However, as their ratings show, students recognized high importance of introductory presentations on a content area of English law, which constitute the first part of their legal language classes. Almost $60 \%$ of all respondents find it extremely important for their efficient study of legal terminology to know about the legal content of a specific area within the English legal system, its structure and regulations, and to be exposed to the contextual use of language in this particular branch of law. Further $26,6 \%$ rated it as very important and $10,3 \%$ as important. It can easily be calculated that $96,8 \%$ of all students (almost all!) highly value the content knowledge and are aware that, owing to different concepts, classifications and regulations within different legal systems, the knowledge of foreign law facilitates the study of legal terminology.

Table 1-2. Students' perception of the importance of different sources of knowledge for successful acquisition of English legal terminology

\begin{tabular}{|c|c|c|c|c|c|}
\hline & Unimportant & $\begin{array}{c}\text { Less } \\
\text { important }\end{array}$ & Important & $\begin{array}{c}\text { Very } \\
\text { important }\end{array}$ & $\begin{array}{c}\text { Extremely } \\
\text { important }\end{array}$ \\
\hline Course book text & $1,9 \%$ & $10,3 \%$ & $31,8 \%$ & $38,3 \%$ & $17,8 \%$ \\
\hline $\begin{array}{c}\text { Introduct. } \\
\text { presentat. onEnglish } \\
\text { law }\end{array}$ & $1,4 \%$ & $2,8 \%$ & $10,3 \%$ & $26,6 \%$ & $58,9 \%$ \\
\hline Bilingual dict. & $3,7 \%$ & $15,9 \%$ & $33,2 \%$ & $26,6 \%$ & $20,6 \%$ \\
\hline Monoling. dict. & $7,9 \%$ & $25,7 \%$ & $30,8 \%$ & $26,2 \%$ & $9,3 \%$ \\
\hline Legal encycl. & $20,6 \%$ & $31,8 \%$ & $30,4 \%$ & $12,1 \%$ & $5,1 \%$ \\
\hline $\begin{array}{c}\text { Additional reading in } \\
\text { legal English }\end{array}$ & $20,6 \%$ & $39,3 \%$ & $28,5 \%$ & $10,3 \%$ & $1,4 \%$ \\
\hline
\end{tabular}


Concerning the most efficient method(s) of acquiring legal terminology, most students indicated that a combination of two or even more methods makes the legal terminology study more efficient. The collected data reveal that translation of a particular terms into their mother tongue, i.e. finding a Croatian equivalent for a particular English term is extremely important to students $(62,2 \%)$. Many also stated that comparison of terminology in the Croatian and English legal system facilitates their learning a lot (even $45,8 \%$ indicated this method as very rewarding). The second most efficient method according to the survey is explaining an English term in the context of English law. Even $55,6 \%$ of all respondents find it essential to learn terminology in the original context. Defining in English seems to be very popular with students as well (46,2 \% indicated it as an effective way to study terminology).

Table 1-3. The most efficient method(s) of legal terminology acquisition

\begin{tabular}{|l|c|}
\hline \multicolumn{1}{|c|}{ Method } & $\mathbf{\%}$ \\
\hline Reading and translation & 62,2 \\
\hline Explaining an English term in the context of English law & 55,6 \\
\hline Defining in Croatian & 50,7 \\
\hline Defining in English & 46,2 \\
\hline Comparison of legal terms and their meanings in both languages & 45,8 \\
\hline Some other way & 0,9 \\
\hline
\end{tabular}

The difficulties the students encounter when studying legal terminology confirmed the conclusion that can be drawn from the previously mentioned statistical data. They namely strongly stressed three problems:

1. their lack of legal knowledge in general and Croatian legal terminology and law (they study legal areas in English which they still do not know about in their own legal system);

2. non-existance of terminological equivalents and hence no translation into Croatian;

3. different legal systems, which makes the understanding difficult.

Since it has been stressed by students as extremely important to know Croatian equivalents for the English terminology wherever possible and to have knowledge of domestic law prior to the study of legal English, and, since they obviously highly value learning in the context of English law, it can be concluded that their answers here once again confirmed the importance of legal content for successful legal language acquisition.

\subsubsection{Section III}

Although most respondents recognized that good knowledge of Croatian legal terminology and the Croatian law contributes to greater success with the acquisition of legal English, the majority of students did not think anything should be changed about the position the legal language courses occupy in the overall curriculum. 69,6\% indicated that the beginning of law studies is the best time to start a legal language course. In an open-ended question in which they were asked to clarify their answers they 
emphasized a parallel study of both systems and terminology as the most rewarding one for the proper development of basic linguistic ability in the field, although, some of them noted that the language course should follow at least a month after other $1^{\text {st }}$ semester courses. However, 22,4\% were convinced that it is much better to start a legal language course after you already have basic legal knowledge of the Croatian legal system, i.e. in the second half of the law degree programme.

The reasons for such distribution of answers might lie in the fact that the present course focuses on the basic terminology and features of the English/American legal system and in such a course it is not essential to know the area of law in debt. So, the students can cope with what they parallelly learn within other law courses and in the English course (although they pointed out that lack of legal knowledge causes difficulties). On the other hand it might be interpreted as a sign that the selected teaching approach is appropriate in the given circumstances and guarantees successful legal terminology acquisition (at the basic level), so the students feel that there is no need for changes.

The students' responses to the last question, where they expressed how successful they think they are in their legal English studies, also speaks in favour of the effectiveness of the language and content integrated approach. Namely, the majority of the students see themselves as successful with studying legal English. Almost $40 \%$ of all respondents assessed their study of legal English as very successful, $27 \%$ indicated they are extremely successful, and further $25 \%$ think they are successful.

\section{Conclusion}

As the survey results show the legal course participants perceive legal content as very important for successful legal language and terminology study. Studying terminology in the context of the legal system to which it belongs and being able to draw comparisons with the national system and terms facilitates their accurate and precise acquisition of foreign legal vocabulary. Therefore, it is necessary to combine legal language teaching with teaching of the features of the foreign legal system for the purpose of contextualized learning. In this respect content-based language instruction (CBI) seems to be the appropriate approach to legal language instruction. As for the best time to start a legal language course, we can conclude that, if legal language is taught only at the basic level for which the in-debt knowledge of law is not necessary and the students can learn enough through the content presented in the class and parallel study of national law, then legal language study can be sufficiently successful even if the course is attended at the beginning of the law degree programme (especially if the same legal areas are dealt with in other law courses). However, as students' responses to most questions, as well as the author's teaching experience indicate, even in such circumstances where only the basics of a foreign legal language are taught, content knowledge is extremely helpful and it is highly recommendable to move a legal language course towards the middle of the law degree programme. Owing to the better legal knowledge acquired by then, the language of different branches of law can be studied in more detail and the overall teaching and learning success can be greater. 


\section{References}

Basturkmen, Helen \& Elder, Catherine. 2006. "The Practice of LSP”. In The Handbook of Applied Linguistics, edited by Davies, Alan \& Elder, Catherine, 285-303. Oxford: Blackwell Publishing Ltd.

Brinton, Donna M., Snow, Marguerite Ann \& Wesche, Marjorie Bingham. 1989. Content-Based Second Language Instruction. New York: Newbury 1989.

Buhlmann, Rosemarie, Fearns, Anneliese. 2000. Handbuch des Fachsprachenunterrichts. Tübingen: Gunter Narr Verlag.

Bukovčan, Dragica. 2009. Od Teorije do prakse u jeziku struke. Zagreb: Školska knjiga, d.d.

Fortanet-Gomez, Inmaculada \& Räisänen, Christina A. (ed.). 2008. ESP in European Higher Education: Integratomg Language and Content. Amsterdam/Philadelphia: John Benjamins B.V.

Gibbons, John. 2006. "Language and the Law". In The Handbook of Applied Linguistics, edited by Davies, Alan \& Elder, Catherine, 285-303. Oxford: Blackwell Publishing Ltd..

Hutchinson, Tom \& Waters, Alan. 2005. English for Specific Purposes. Cambridge: Cambridge University Press.

Juez, Ma Teresa Alejos. 2006. Linking language and content: ESL instruction through legal topics. In Proceedings of the 5th International AELFE Conference, 327-332. http://www.unizar.es/aelfe2006/ALEFE06/2.\%20didactics/46.pdf

Kim, Dan. 2008. English for Occupational Purposes: One Language? London/New York: Continuum.

Stryker, S.N. \& Leaver, B.L. (eds). 1997. Content-based Instruction in Foreign Language Education. Washington D.C.: Georgetown University Press. 